\title{
Dopaminergic Modulation of Gap Junction Permeability between Amacrine Cells in Mammalian Retina
}

\author{
Edith C. G. M. Hampson, ${ }^{1}$ David I. Vaney, ${ }^{1}$ and Reto Weiler ${ }^{2}$ \\ 'Vision, Touch and Hearing Research Centre, Department of Physiology and Pharmacology, University of Queensland, \\ Brisbane 4072, Australia and 'Department of Neurobiology, University of Oldenburg, Oldenburg 2900, Germany
}

In mammalian retina, the rod bipolar cells synapse on the All amacrine cells, which are therefore the third-order neurons in the rod-signal pathway. The All amacrine cells are connected by gap junctions, both to each other and to fourthorder, On-center cone bipolar cells. They also receive synaptic input from the dopaminergic amacrine cells, and in this study, we investigated whether dopamine modulates the permeability of the gap junctions between All amacrine cells in the isolated rabbit retina. The small biotinylated tracer Neurobiotin was injected into nuclear yellow-labeled All cells under direct microscopic control. The extent of tracer coupling to neighboring All cells, 40-60 min after Neurobiotin injection ( $0.5 \mathrm{nA}$ for $60 \mathrm{sec}$ ), provided a standard measure of the permeability of the homologous gap junctions. Under control conditions, individual All amacrine cells were coupled to $73 \pm 15$ neighboring cells, and this was unaffected by changes in $\mathrm{pH}$ from 6.6 to 7.8. Exogenous dopamine significantly reduced the tracer coupling at concentrations as low as $10 \mathrm{~nm}$ (26 \pm 16 cells), with the effect increasing with dopamine concentration up to $10 \mu \mathrm{M}$ ( $6 \pm 4$ cells). The uncoupling effect of dopamine was both blocked by the selective $D_{1}$ antagonist $\mathrm{SCH}-23390(10 \mu \mathrm{M})$ and mimicked by the specific $D_{1}$ agonist SKF-38393 (500 $\left.\mu \mathrm{M}\right)$. Moreover, the All amacrine cells were also uncoupled when the retina was incubated in forskolin $(60 \mu \mathrm{M})$ and isobutylmethylxanthine $(200 \mu \mathrm{M})$. Taken together, these results indicated that the uncoupling was mediated by a $D_{1}$-like receptor that stimulates CAMP production. Although the selective $D_{1}$ antagonist on its own did not increase tracer coupling, suggesting that there was little release of endogenous dopamine in the superfused photo-bleached retina, veratridine-evoked release of endogenous transmitters did uncouple the All amacrine celis, and this effect was blocked by the specific $D_{1}$ antagonist.

Converging evidence indicates that the dopaminergic interneurons in the retina facilitate the transition from rod-dominated to cone-dominated vision (Witkovsky and Dearry, 1992). In the outer retina of lower vertebrates, dopamine modulates a diverse range of processes, including light-adaptive retinomotor move-

\footnotetext{
Received May 15, 1992; revised July 8, 1992; accepted July 10, 1992.

We thank Christopher Palmer, Denise Crook, and Guy Elston for expert technical assistance. This study was supported by an NH\&MRC project grant to D.I.V.,

University of Queensland special project grants to E.C.G.M.H. and D.I.V., and

a Volkswagen-Stiftung award to R.W.

Correspondence should be addressed to Edith C. G. M. Hampson, Ph.D., at the above address.

Copyright (C) 1992 Society for Neuroscience $0270-6474 / 92 / 124911-12 \$ 05.00 / 0$
}

ments (Dearry and Burnside, 1986), the sensitivity of secondorder retinal neurons (Knapp and Dowling, 1987), the formation of horizontal cell spinules (Weiler et al., 1988), and the permeability and connexon density of the gap junctions between retinal horizontal cells (Teranishi et al., 1983, 1984; Piccolino et al., 1984; Lasater and Dowling, 1985; Baldsridge et al., 1987). Retinal dopamine, acting through a $\mathrm{D}_{1}$ dopamine receptor, greatly reduces the open probability of the gap junction channels, without reducing their unitary conductance (McMahon et al., 1989). This increases the coupling resistance between horizontal cells, thus reducing their receptive-field size. The discovery that a neurotransmitter can modulate the activity of electrical synapses has changed our view of gap junctions: they are now perceived as dynamic components of neuronal circuits, rather than passive connections.

Although dopamine's role in modulating the junctional coupling between horizontal cells has been well characterized in lower vertebrates (Dowling, 1991), it is not known whether dopamine also affects the permeability of gap junctions between inner retinal neurons or between horizontal cells in mammalian retina. In most mammals, the dopaminergic amacrine cells are present at low density and their processes form a rich plexus in stratum 1 of the inner plexiform layer, adjacent to the amacrine sublayer of the inner nuclear layer (Ehinger, 1982). Intracellular injectións of dopaminergic amacrine cells in cat, rabbit, and monkey retinas revealed that they give rise both to a sparse dendritic tree of 400-800 $\mu \mathrm{m}$ diameter (Voigt and Wässle, 1987; Tauchi et al., 1990) and to one or more axon-like processes whose arborizations may extend for $5 \mathrm{~mm}$ from the cell body (Dacey, 1990; Vaney, 1992). Much of the synaptic output of the fine varicose processes is directed to the cell bodies and proximal dendrites of the AII (rod) amacrine cells (Pourcho, 1982; Voigt and Wässle, 1987). It was proposed, by analogy to horizontal cells, that the dopaminergic input to these inner retinal neurons could modulate the permeability of their gap junctions (Mariani et al., 1984; Vaney, 1985).

The AII amacrine cells are the third-order neurons in the rodsignal pathway (Kolb and Famiglietti, 1974). They have a narrow-field bistratified morphology, with distinctive "lobular" dendrites in strata 1 and 2 of the inner plexiform layer and more extensive "arboreal" dendrites in strata 3-5 (Famiglietti and Kolb, 1975; Vaney, 1985; Dacheux and Raviola, 1986; Mills and Massey, 1991; Vaney et al., 1991a). The AII amacrine cells receive substantial input from rod bipolar axons on thcir arboreal dendrites (Sterling et al., 1988; Strettoi et al., 1990; Vaney et al., 1991a), and both types of neurons respond to diffuse illumination with a transient-sustained depolarization that is rod dominated (Dacheux and Raviola, 1986). In rabbit retina, 
the lobular dendrites make chemical synapses with cone bipolar axons in sublamina $a$ while the arboreal dendrites make gap junctions with cone bipolar axons in sublamina $b$ (Strettoi et al., 1989, 1990; cf. Dacheux and Raviola, 1986). The chemical synapses are probably glycinergic (Pourcho, 1980; Pourcho and Goebel, 1985; Müller et al., 1988), and thus the rod signal in the On-center AII amacrine cells is fed through sign-inverting inhibitory synapses into Off-center cone bipolars and through sign-conserving electrical synapses into On-center cone bipolars. In addition, neighboring AII cells are connectcd by gap junctions between their overlapping arboreal dendrites (Famiglietti and Kolb, 1975; Kolb, 1979; Dacheux and Raviola, 1986; Strettoi et al., 1990).

Although Lucifer yellow (457 Da) and carboxyfluorescein (376 Da) were thought to be junction-permeant molecules (Stewart, 1978; Rao et al., 1986), no dye coupling is observed when they are injected into AII amacrine cells in cat and rabbit retinas (Vaney, 1985; Vaney et al., 1991a). However, when individual AII cells are injected with the small biotinylated tracers, biocytin (373 Da; Horikawa and Armstrong, 1988) and Neurobiotin (286 $\mathrm{Da}$; Kita and Armstrong, 1991), the injected neuron shows strong tracer coupling, both to neighboring AII cells and to cone bipolar cells underlying its dendritic tree (Vaney, 1991; Vaney et al., $1991 \mathrm{~b}$ ), thus reflecting the gap junction connectivity described from electron microscopy. Other retinal neurons that are connected by gap junctions, or that appear to be electrotonically coupled, also show tracer coupling when injected with Neurobiotin (Vaney, 1991).

In the intact retina, tracer coupling may provide a more direct assay of gap junction permeability than do electrophysiological measures of the coupling resistance, which are confounded by changes in the leakage resistance across the surface membrane. In this study, we injected Neurobiotin into identified AII cells in superfused rabbit retina and, after a period of equilibration, measured the extent of tracer coupling through the AII syncytium. This preparation was used to study the effect of dopamine and other agents on the permeability of the gap junctions between AII amacrine cells; our results indicate that dopamine greatly reduces Neurobiotin tracer coupling and that this effect is probably mediated by $\mathrm{D}_{1}$ dopamine receptor.

Parts of this study have been reported previously in abstract form (Hampson and Vaney, 1992).

\section{Materials and Methods}

The techniques for dye filling of microscopically identified neurons in superfused mammalian retina have been developed in our laboratory over the last 10 years (Vaney, 1984, 1985, 1986, 1991; Vaney et al., 1991a). Many alterations and additions have been made to the original protocols, and thus our current procedures are described here in detail.

Isolated retina preparation. Adult pigmented rabbits of either sex were anesthetized with $4 \%$ halothane in air, and then nuclear yellow $(5 \mu \mathrm{g}$; Hoechst) in $50 \mu$ l deionized water was injected into the posterior chamber of each eye (Vaney et al., 199 la). Some $24 \mathrm{hr}$ later, the animal was overdosed by intravenous injection of pentobarbitone, the eyes enucleated and hemisected, and the eyecups immersed in modified Ames medium at room temperature. Each liter of carbogenated medium $(\mathrm{pH}$ $7.3 \pm 0.2$ ) contained $8.9 \mathrm{gm}$ of Ames powder (Commonwealth Serum Laboratories), $1.4 \mathrm{gm} \mathrm{NaHCO}, 0.8 \mathrm{gm}$ glucose, and $0.4 \mathrm{gm} \mathrm{NaCl}$. The retina inferior to the myelinated band was dissected from the sclera, floated onto a glass slide with the photoreceptors upward, and cut into three or four segments that were then separated. Excess medium was blotted off the slide, and a black Millipore filter (AABG 0025) was gently lowered onto each retinal segment. The filters were irrigated with Ames medium and then turned over to expose the attached retina. The wholemounts were preincubated for at least $30 \mathrm{~min}$ in either control or experimental medium at $32 \pm 2^{\circ} \mathrm{C}(\mathrm{pH} 7.4 \pm 0.2)$ before being transferred to a heated tissue chamber on a Zeiss fixed-stage microscope and superfused with preheated medium at $1 \mathrm{ml} / \mathrm{min}$.

Neurobiotin injections. The injection micropipettes contained $1 \% \mathrm{Lu}-$ cifer yellow $\mathrm{CH}$ (Sigma) and 3\% N-(2-aminoethyl)-biotinamide hydrochloride (Neurobiotin, Vector Laboratories) in $0.1 \mathrm{M}$ Tris buffer, $\mathrm{pH}$ 7.6 (Vaney, 1991); they had an impedance of 150-450 M 2 . The micropipette, which was angled at about $30^{\circ}$ to the retinal surface, was coarsely positioned under a $6.3 \times$ objective and then finely positioned under a $40 \times$ water-immersion objective (Zeiss) using a Leitz micromanipulator. The micropipette and the nuclear yellow-labeled cells were viewed under violet excitation (355-425 nm); photo-bleaching was minimized by a remote-controlled shutter and a neutral-density filter wheel located in front of the $50 \mathrm{~W}$ mercury lamp. The micropipette was slowly advanced along its axis until its fluorescent tip dimpled the target neuron, and then the amplifier was briefly oscillated to facilitate penetration of the cell membrane. Successful impalement was confirmed by the clean passage of Lucifer yellow into the cell body during oscillation. The Neurobiotin was then iontophoresed with a positive current of $0.5 \mathrm{nA}$ for $60 \mathrm{sec}$. About six AII cells were successfully injected over a $20 \mathrm{~min}$ period, after which the retina was postincubated in the control or experimental medium for a further $40 \mathrm{~min}$. The injected AII cells were located in mid-peripheral retina, some 4-7 $\mathrm{mm}$ inferior of the visual streak; at this eccentricity, there are $900-1200 \mathrm{AII}$ cells $/ \mathrm{mm}^{2}$ (Vaney, 1990; Vaney et al., 1991a).

Processing and analysis. The retinal whole-mounts were fixed for 60 $\mathrm{min}$ in $4 \%$ paraformaldehyde in $0.1 \mathrm{~m}$ phosphate buffer, $\mathrm{pH} 7.4$. The tissue was removed from the Millipore filter, incubated overnight in $0.5 \%$ Triton-X in phosphate buffer, and then reacted with $1: 500$ streptavidin-biotinylated-peroxidase complex (Amersham) for $3 \mathrm{hr}$. The retina was incubated for $10 \mathrm{~min}$ in $0.05 \%$ 3,3'-diaminobenzidine (Sigma) in phosphate buffer, reacted with $0.01 \%$ hydrogen peroxide for another $10 \mathrm{~min}$, and then coverslipped in $50 \%$ glycerine in phosphate buffer (Vaney, 1991). The retinal whole-mounts were viewed under a $20 \times$ objective, and the arrays of tracer-coupled cells were mapped under a drawing tube; this magnification allowed a clear distinction between the AII cell bodies in one focal plane and the cone bipolar cells in an underlying focal plane. The microscopic analysis was undertaken by one person (E.C.G.M.H.) so that the subjective criteria for identifying whether an AII cell contained a threshold level of Neurobiotin remained consistent throughout the experimental series. The number of AII cells that were tracer coupled to each injected cell was counted, and the combined results for each experimental protocol were usually scored as the mean \pm the standard deviation, except where stated. Differences between protocols were compared using an unpaired Student's $t$ test; a $p$ value less than 0.05 was considered statistically significant.

Drugs and controls. Dopamine hydrochloride, ( \pm )-SKF-38393 [Research Biochemical Inc. (RBI)], LY-171555 (RBI), bupropion hydrochloride (RBI), (-)-bicuculline methbromide (RBI), and amphetamine sulfate (U.S. Pharmacopoeia) were all dissolved directly in Ames medium. $R(+)-\mathrm{SCH}-23390$ hydrochloride (RBI), veratridine (RBI), forskolin, and isobutylmethylxanthine (IBMX) were first dissolved in 90$100 \%$ ethanol and then diluted in Ames medium. Those drugs whose supplier is not specified were obtained from Sigma. Solutions containing dopamine, SKF-38393, or LY-171555 were protected from oxidation by the addition of ascorbic acid and pargyline, both at $10 \mathrm{nM}$ or 100 $\mu \mathrm{M}$. Solutions containing SCH-23390 had a final ethanol concentration of $0.9 \%$. The tracer coupling between AII cells in normal Ames medium was not significantly different from that in control media containing either low-concentration antioxidants, high-concentration antioxidants, or $0.9 \%$ ethanol. To establish whether the retina was viable for $4-6 \mathrm{hr}$

Figure 1. High-power micrographs of the pattern of tracer coupling following Neurobiotin injection into a single AII amacrine cell (asterisk), as viewed through differential interference contrast optics. The injected cell was tracer coupled to a regular array of somata in the amacrine sublayer $(A)$ and to an irrcgular mosaic of bipolar cclls, whosc smaller somata were located deeper in the inner nuclear layer $(B)$. The tracer-coupled amacrine cells gave rise both to lobular dendrites in sublamina $a$ of the inner plexiform layer $(C)$ and to arboreal dendrites in sublamina $b(D)$, thus establishing that they were AII amacrine cells. Scale bar, $20 \mu \mathrm{m}$. 

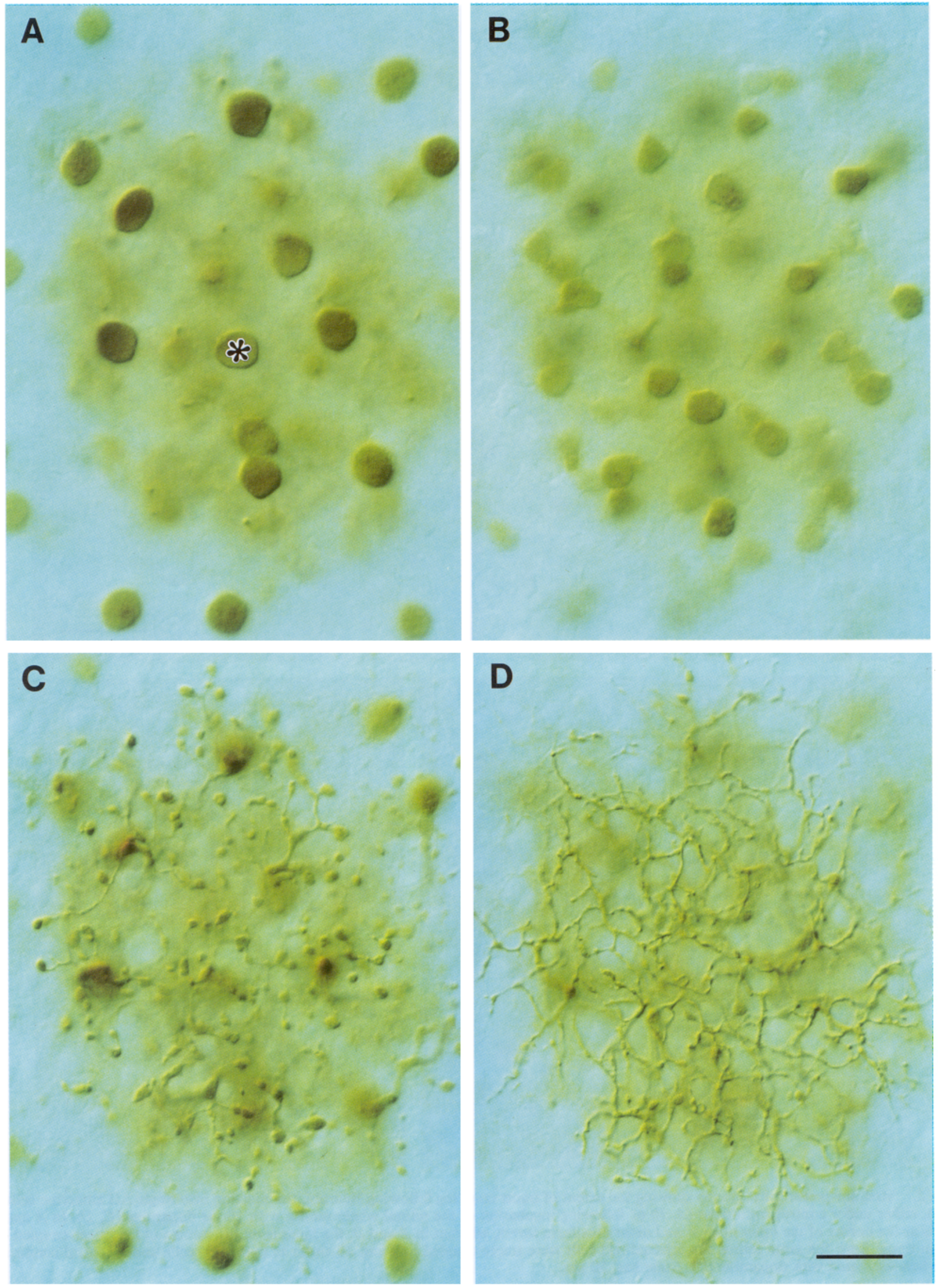

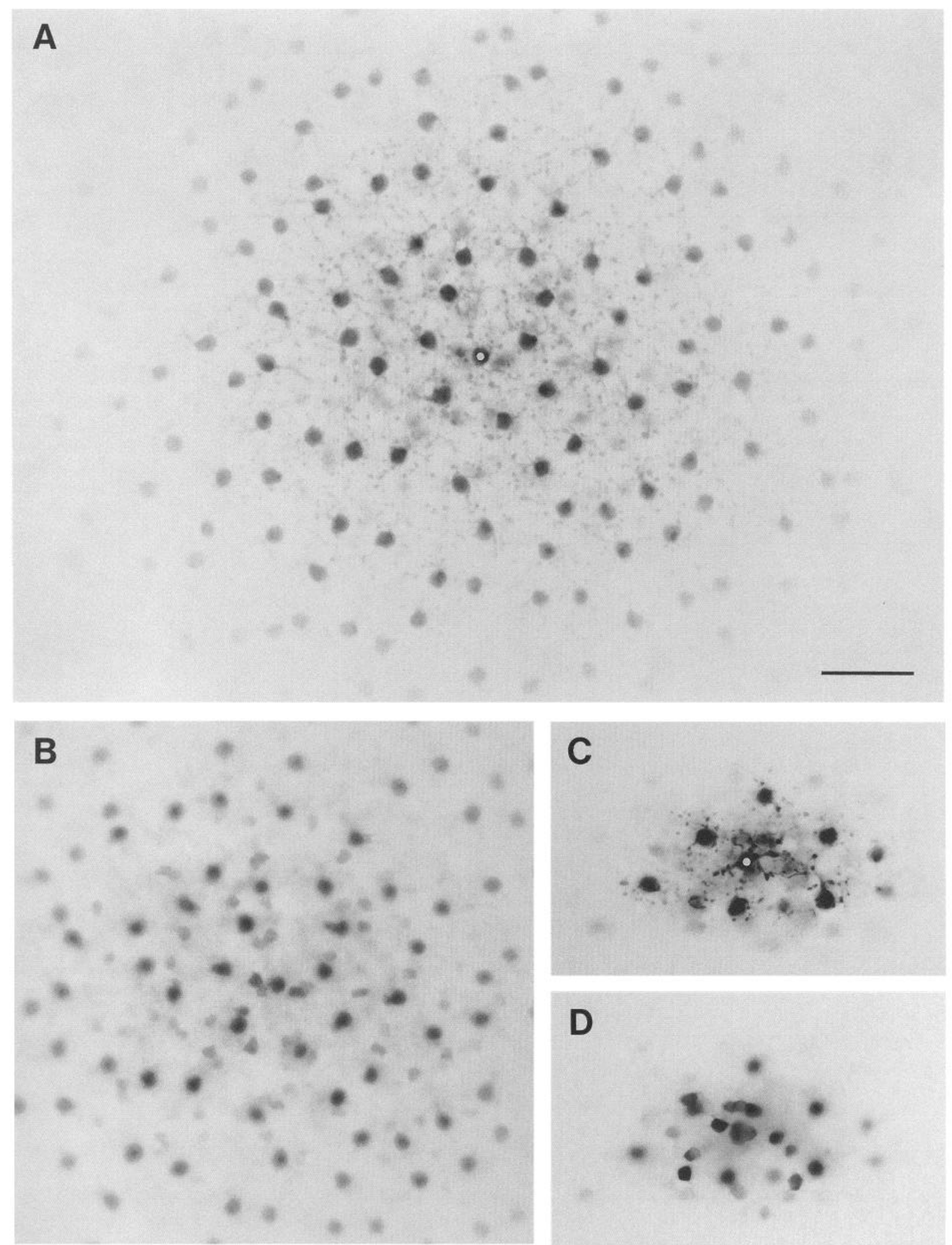

Figure 2. Medium-power micrographs showing the extent of tracer coupling following Neurobiotin injection into single AII amacrine cells (white circles), either under control conditions $(A, B)$ or following incubation of the retinal whole-mount with $10 \mu \mathrm{M}$ dopamine $(C, D)$. In $A$ and $C$ the focus is at the border of the inner nuclear and inner plexiform layers, whereas in $B$ and $D$, the focus is on the somata of the tracer-coupled bipolar cells. In tissue from the same retina, the injected AII cells were tracer coupled to about 10 times as many AII cells under control conditions $(A)$ than when incubated with dopamine $(C)$. Scale bar, $50 \mu \mathrm{m}$. 


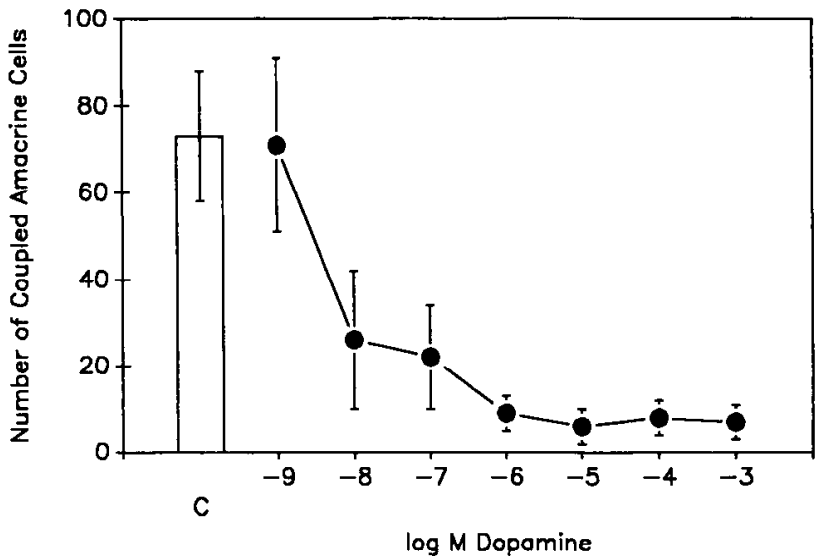

Figure 3. Semilogarithmic dose-response plot of the number of tracercoupled AII amacrine cells $( \pm$ SEM) against the concentration of exogenous dopamine ( $1 \mathrm{nM}$ to $1 \mathrm{mM}$ ) in the incubation medium $(n=4$ $28)$. Maximum tracer coupling occurred under control $(C)$ conditions $(n=130)$.

in vitro, tissue incubated in control medium was injected at the beginning and end of most experiments. Thus, it was confirmed that the pharmacological results were not confounded by changes in the permeability of the gap junctions during the course of the experiment.

\section{Results}

Tracer coupling pattern of AII amacrine cells

As reported previously (Vaney, 1990; Vaney et al., 1991a,b), intravitreal injection of nuclear yellow produced strong metachromatic labeling of the rabbit retina, with the nuclei of AII amacrine cells fluorescing bright yellow under violet excitation and the nuclei of other amacrine cells fluorescing blue. The distinctive bistratified morphology of the AII amacrine cells was revealed when the yellow-fluorescent nuclei were intracellularly injected with Lucifer yellow in the isolated superfused retina. However, the Lucifer-filled cells showed no dye coupling to surrounding neurons, both under control conditions and when incubated in media containing either dopamine or its antagonists.

When the AII amacrine cells were injected with Neurobiotin, by contrast, they showed extensive tracer coupling to many neurons whose cell bodies were located throughout the inner nuclear layer (Vaney, 1991). A regular array of cell bodies in the amacrine sublayer showed the strongest labeling (Fig. 1 $\mathrm{A}$ ); each cell gave rise to lobular dendrites in sublamina $a$ of the inner plexiform layer (Fig. 1C) and to arboreal dendrites in sublamina $b$ (Fig. $1 D$ ), indicating that they were All amacrine cells. This was confirmed by photographing a retinal field before Neurobiotin injection and later comparing the pattern of ycllowfluorescent cells with the pattern of tracer-coupled cells in the amacrine sublayer: they showed a one-to-one correspondence (not illustrated). No other amacrine cell type appeared to be tracer-coupled to the injected AII cell.

In addition, the array of homologously coupled AII cells was heterologously coupled to an irregular mosaic of bipolar cells, whose smaller cell bodies were located deeper in the inner nuclear layer (Fig. 1B). The coupled bipolar cells had bushy axonal arbors and thus appeared to be cone bipolars rather than rod bipolars (Famiglietti, 1981). The cells varied in their axonal morphology and their density of labeling, indicating that they comprised several types of cone bipolars (D. I. Vaney and E. C. G. M. Hampson, unpublished observations). There were no

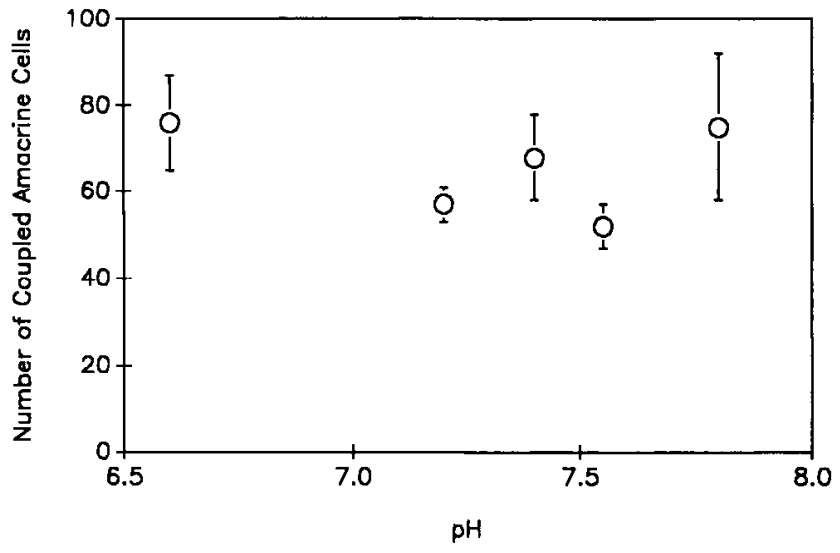

Figure 4. Effect of extracellular $\mathrm{pH}$ on the number of tracer-coupled AII amacrine cells $( \pm$ SEM). There was no significant difference between acidic ( $\mathrm{pH} 6.6)$ and alkaline $(\mathrm{pH} 7.8)$ conditions $(n=4-6)$.

labeled bipolar cells underlying the weakly labeled AII cells farthest from the injected cell, and thus each field of tracercoupled bipolar cells was less extensive than the overlying field of tracer-coupled AII cells.

Although the number of AII cells that were tracer coupled to the injected neuron generally increased with time, a $60 \mathrm{~min}$ incubation did not produce significantly more coupling than a 40 min incubation. The AII cells in each retinal segment were therefore injected over a $20 \mathrm{~min}$ period and the tissue was left to equilibrate for $\mathbf{4 0} \mathrm{min}$ before fixation. In the control preparations, the injected neurons in mid-inferior retina were homologously coupled to 60-140 surrounding AII cells, whose labeling decreased with distance from the injected neuron (Fig. $2 A, B)$.

\section{Modulation of tracer coupling between AII cells}

Effect of exogenous dopamine. In contrast to the extensive tracer coupling that occurred under control conditions, incubation of the retina with exogenous dopamine significantly reduced the tracer coupling between AII amacrine cells. Following incubation in $10 \mu \mathrm{M}$ dopamine, an AII cell injected with Neurobiotin showed only limited coupling to its immediate neighbors, whose arboreal dendrites were in direct contact with the injected neuron (Fig. 2C).

A dose-response curve for the effect of exogenous dopamine on the tracer coupling of AII amacrine cells is shown in Figure 3. The minimum concentration of dopamine that induced significant uncoupling was only $10 \mathrm{nM}$, and a consistent submaximal response was obtained with $100 \mathrm{~nm}$ dopamine. The degree of uncoupling increased with dopamine concentration up to 1$10 \mu \mathrm{M}$ and then remained rather constant.

Effect of $p H$. Treatments that acidify the cytoplasm of coupled cells may decrease the permeability of the gap junctions (Bennett and Spray, 1987; DeVries and Schwartz, 1989). We therefore wished to establish whether the uncoupling induced by dopamine might result from small changes in the $\mathrm{pH}$ of the external medium, rather than from the action of dopamine itself. Incubation media whose $\mathrm{pH}$ ranged from 6.6 to 7.8 were prepared by altering the amount of $\mathrm{NaHCO}_{3}$ in the carbogenated Ames medium. The mean number of tracer-coupled cells in acidic conditions was not significantly different from that in alkaline conditions (Fig. 4), indicating that the uncoupling with dopamine solutions was not caused by changes in external pH. How- 

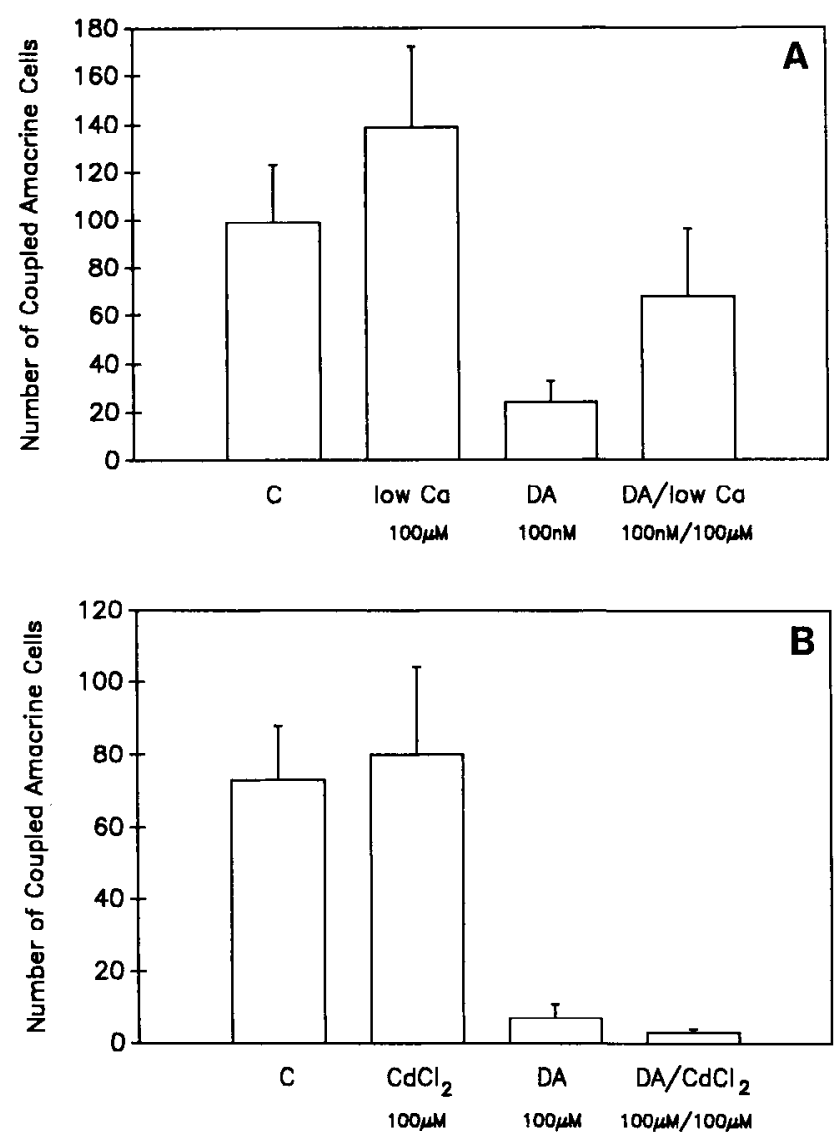

Figure 5. Effect of blocking chemical synaptic transmission either by lowering the external calcium concentration from $1150 \mu \mathrm{M}$ to $100 \mu \mathrm{M}$ $(A ; n=4-6)$ or by adding $100 \mu \mathrm{M} \mathrm{CdCl}_{2}$ to the incubation medium $(B$; $n=2-5)$. The number of tracer-coupled AII amacrine cells $( \pm \mathrm{SD})$ was compared in blocking and control $(C)$ media, in either the presence or absence of $100 \mu \mathrm{M}$ dopamine $(D A)$.

ever, we cannot conclude that acidification does not close the gap junctions between AII cells, because the external medium would be buffered by the tissue.

Effect of low calcium. Chemical synaptic transmission was blocked in two ways. First, the retina was incubated in medium

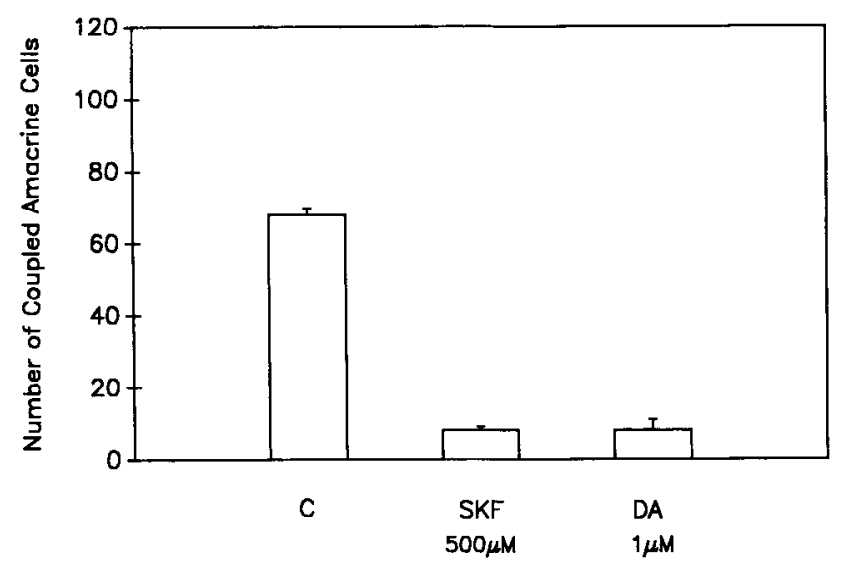

Figure 6. Effect of the specific $\mathrm{D}_{1}$ agonist SKF-38393 $(500 \mu \mathrm{M})$ on the number of tracer-coupled AII amacrine cells $( \pm S D)$; the uncoupling was similar to that produced by a saturating concentration of dopamine ( $D A$; $n=2-4)$. C, control.

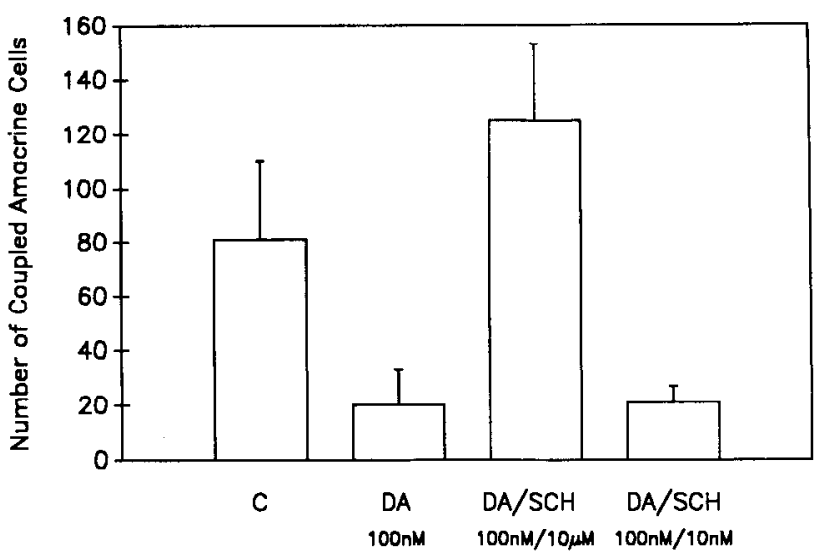

Figure 7. Effect of the specific $\mathrm{D}_{1}$ antagonist $\mathrm{SCH}-23390$ in blocking the uncoupling induced by exogenous dopamine $(D A)$; the retina was incubated in medium containing $100 \mathrm{nM}$ dopamine with high $(10 \mu \mathrm{M})$ or low (10 nM) concentrations of SCH-23390. The error bars represent $\mathrm{SD}(n=4-9)$. $C$, control.

in which the calcium concentration was reduced from $1150 \mu \mathrm{M}$ to $100 \mu \mathrm{M}$. Second, $100 \mu \mathrm{M} \mathrm{CdCl}_{2}$ was added to the normal medium to reduce the influx of calcium during depolarization (Kuan and Scholfield, 1986). Under either of these regimens, the mean number of tracer-coupled cells was somewhat greater than under control conditions. When dopamine was added to the low-calcium medium or the cadmium-containing medium, the tracer coupling was significantly less than in retinal scgments incubated in the experimental medium alone (Fig. 5). Thus, blockade of chemical transmission did not prevent dopamineinduced uncoupling; this indicates that the exogenous dopamine acted directly on the AII amacrine cells, rather than through an intermediate neuron.

\section{Mechanism of dopamine-induced uncoupling}

The following experiments investigated whether the effect of dopamine on tracer coupling was mediated by a $D_{1}$ receptor or a $\mathrm{D}_{2}$ receptor.

Effects of dopamine agonists and antagonists. Incubation of the retina with the specific $D_{1}$ agonist SKF-38393 (500 $\left.\mu \mathrm{M}\right)$ uncoupled the AII amacrine cells to the same extent as saturating concentrations of dopamine (Fig. 6). Conversely, the specific $D_{1}$ antagonist $\mathrm{SCH}-23390(10 \mu \mathrm{M})$ reversed the uncoupling effect of dopamine (100 $\mathrm{nM}$ ), giving rise to even greater coupling than found under control conditions (Fig. 7). A low concentration of SCH-23390 (10 nM) only slightly antagonized the uncoupling effect of dopamine, and it appeared that the minimum effective concentration of SCH-23390 was at least $100 \mathrm{nM}$. The specific $\mathrm{D}_{2}$ agonist LY-171555 (100 $\left.\mu \mathrm{M}\right)$ also uncoupled the AII amacrine cells but to a lesser extent than dopamine or SKF-38393. Rather surprisingly, however, the effect of LY-171555 was blocked by the specific $\mathrm{D}_{1}$ antagonist $\mathrm{SCH}-23390$. This suggested that the $D_{2}$ agonist was stimulating a $D_{1}$ receptor or that the dopaminergic receptor involved has unusual hybrid characteristics. Ongoing experiments will attempt to resolve these paradoxical findings.

Effects of forskolin and IBMX. The above experiments indicated that $D_{1}$-like receptors may mediate the effects of dopamine on tracer coupling between AII amacrine cells. If that was the case, then the activated receptors should stimulate adenylate cyclase activity in the AII cells, thus increasing the level 


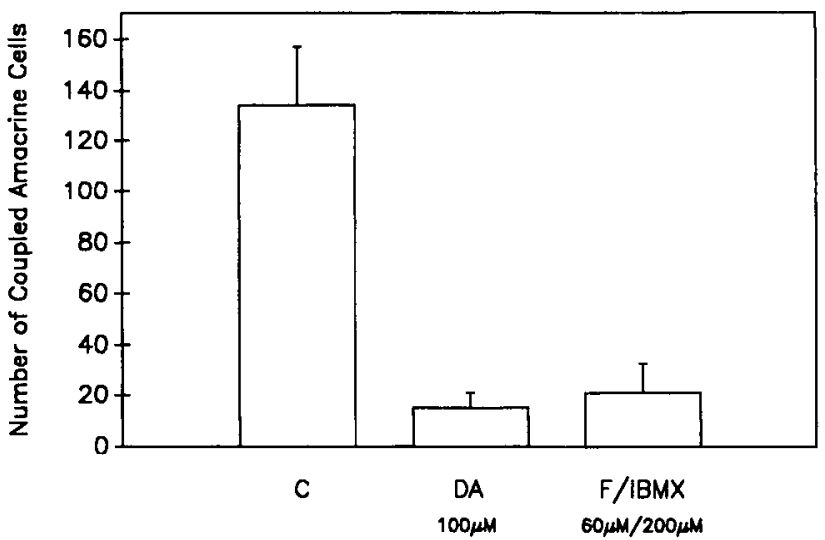

Figure 8. Effect of forskolin $(F ; 60 \mu \mathrm{M})$ and IBMX $(200 \mu \mathrm{M})$ on the number of tracer-coupled AII amacrine cells $( \pm \mathrm{SD})$; the combined effect of these drugs was similar to that produced by a high concentration of dopamine $(n=6)$. $C$, control.

of cAMP (Kebabian and Calne, 1979). Conversely, other treatments that increase intracellular cAMP should also reduce the tracer coupling between AII cells (Teranishi et al., 1983, 1984; Piccolino et al., 1984). We therefore examined the effects on tracer coupling of forskolin, which stimulates adenylate cyclase (Seamon et al., 1981), and of IBMX, which inhibits cyclic nucleotide phosphodiesterase, the enzyme that inactivates cAMP. Incubation of the retina with both forskolin $(60 \mu \mathrm{M})$ and IBMX (200 $\mu \mathrm{M})$ induced significant $(p<0.00 \mathrm{I})$ uncoupling, comparable to that produced by high concentrations of dopamine (Fig. 8).

Time course of drug action. In order to characterize the time course of the uncoupling effect, the superfusate was switched from the control to the drug-containing medium only after the first cell in the segment was injected with Neurobiotin; complete exchange of the medium in the tissue chamber occurred within $4 \mathrm{~min}$. In these time course experiments, 7-12 cells were injected over a $\mathbf{4 0}$ min period, after which the retina was postincubated in the drug-containing medium for a further $30 \mathrm{~min}$.

Figure 9 shows the number of AII cells that were coupled to each injected neuron in four experiments examining the effect of either dopamine $(100 \mu \mathrm{M})$ or forskolin/IBMX $(60 \mu \mathrm{M} / 200$ $\mu \mathrm{M})$. It appeared that the AII cells did not begin to uncouple significantly until about $20 \mathrm{~min}$ after the drug was added to the superfusate. The cells that had not been exposed to the drug before injection were tracer coupled to about three times as many neurons as the cells that were incubated with the drug for $30 \mathrm{~min}$ before injection. In control experiments, where the normal medium was used throughout the injection and incubation periods, the decline in tracer coupling with shorter incubation times was much less pronounced (Fig. 9).

\section{Effects of endogenous dopamine}

On their own, neither the $D_{1}$ antagonist, SCH-23390 (Fig. 10) nor the nonspecific antagonist haloperidol (not shown) had any significant effect on the tracer coupling of AII amacrine cells, in contrast to their ability to reverse the dramatic uncoupling induced by low concentrations of cxogenous dopamine (Fig. 7). This indicated that, in the isolated superfused retina preparation, there was not a tonic release of endogenous dopamine that served to uncouple the AII amacrine syncytium partially. Preliminary attempts to stimulate endogenous dopamine release
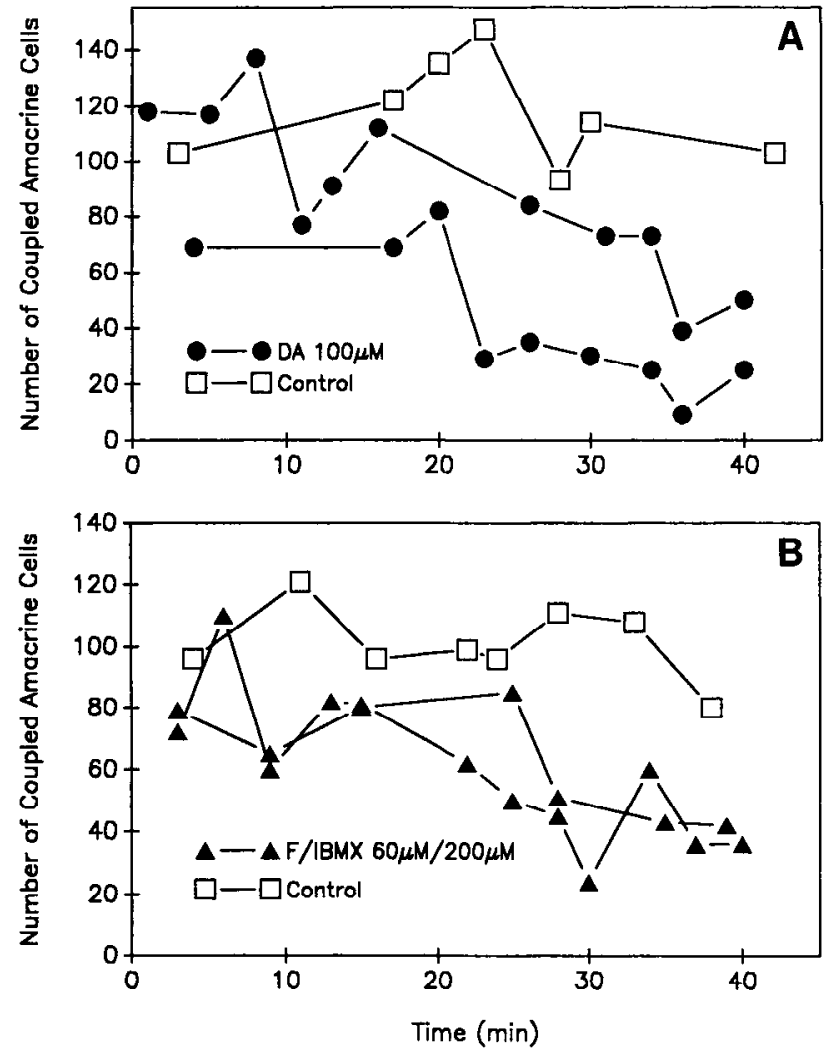

Figure 9. Time course of the effects of either $100 \mu \mathrm{M}$ dopamine ( $D A$; $A$ ) or $60 \mu \mathrm{M}$ forskolin $(F)$ and $200 \mu \mathrm{M}$ IBMX $(B)$ on the tracer coupling of AII amacrine cells. Each set of data points was obtained from one retinal segment; the six data sets were obtained from four different eyes. Each segment was initially superfused with the control (drug-free) medium, and the first AII cell was injected with Neurobiotin. At time 0 min, the superfusate to four segments was switched from the control to the experimental (drug-containing) medium. Thereafter, the AII cells were injected with Neurobiotin over a $40 \mathrm{~min}$ period and then left to equilibrate for $30 \mathrm{~min}$ prior to fixation.

using whole-field flicker $(2 \mathrm{~Hz})$, both before and during the injection period, failed to alter the extent of tracer coupling. Moreover, neither bicuculline $(100 \mu \mathrm{M})$ nor amphetamine sulfate $(80 \mu \mathrm{M})$ had a significant effect on the tracer coupling, where-

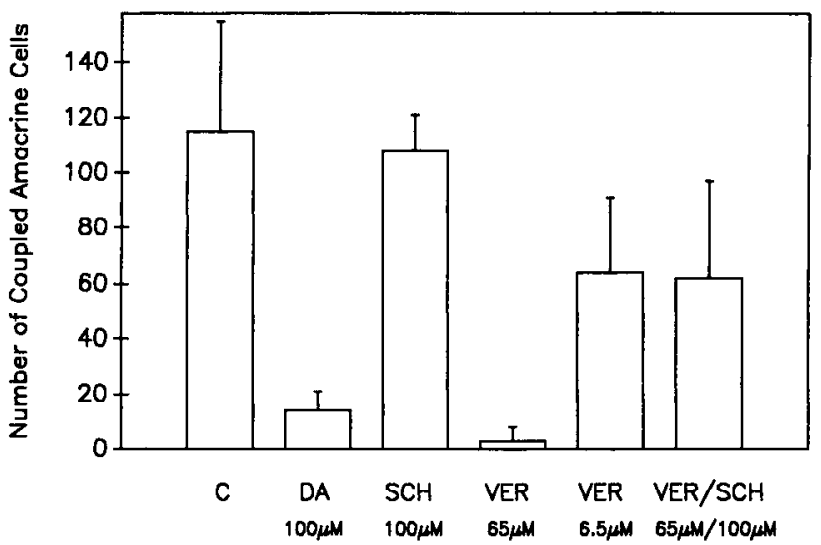

Figure 10. Effect of veratridine on the number of tracer-coupled AII amacrine cells $( \pm \mathrm{SD})$. The retina was incubated with either $100 \mu \mathrm{M}$ dopamine $(D A), 100 \mu \mathrm{M} \mathrm{SCH}-23390$, or veratridine (VER) at high (65 $\mu \mathrm{M})$ or low $(6.5 \mu \mathrm{M})$ concentrations. The effect of $\mathrm{SCH}-23390$, a specific $D_{1}$ antagonist, in blocking the uncoupling induced by veratridine was also examined. $(n=5-10)$. $C$, control. 
as in turtle retina, both drugs have been shown to reduce horizontal cell coupling through the release of endogenous dopamine (Piccolino et al., 1987).

Veratridine stimulates the release of neurotransmitters from spike-generating neurons (Blaustein, 1975) and has been shown to uncouple horizontal cells in the turtle retina, probably by releasing endogenous dopamine (Piccolino et al., 1987). Veratridine reduced the tracer coupling between AII amacrine cells in a dose-dependent manner, inducing partial uncoupling at 6.5 $\mu \mathrm{M}$ and almost complete uncoupling at $65 \mu \mathrm{M}$ (Fig. 10). The uncoupling induced by $25 \mu \mathrm{M}$ veratridine was further increased with the addition of bupropion $(100 \mu \mathrm{M})$, which inhibits dopamine uptake (not illustrated). The uncoupling effect of veratridine $(65 \mu \mathrm{M})$ on AII amacrine cells was largely blocked by incubating the retina with dopaminergic antagonists, either SCH$23390(100 \mu \mathrm{M})$ or haloperidol $(100 \mu \mathrm{M})$. This key experiment indicated that uncoupling can be induced by endogenous dopamine released from the retina.

\section{Discussion}

\section{Homologous coupling between AII amacrine cells}

When an AII amacrine cell was injected with the small biotinylated tracer Neurobiotin, it showed tracer coupling to 60-140 surrounding AII cells within 40-60 min of injection (Vaney, 1991). This homologous coupling is parsimoniously attributed to the diffusion of Neurobiotin through the extensive gap junctions that connect the arboreal dendrites of AII amacrine cells (Famiglietti and Kolb, 1975; Kolb, 1979; Dacheux and Raviola, 1986; Strettoi et al., 1990). Certainly, extracellular injection of Neurobiotin did not produce any labeling of the AII amacrine cells or of other neurons in the retina.

The wide range in the number of coupled AII cells reflected two sources of variability: the substantial variation between rabbits was compounded by more limited variation within each retinal segment. In the latter case, the variation was independent of either the order of injection or the local density of AII cells. It probably arose from variability in the amount of tracer that was actually injected into the AII cell, perhaps resulting from subtle differences in either the micropipettes or the cell penetrations.

This variability notwithstanding, the extent of Neurobiotin tracer coupling through the AII array provides a good measure of the permeability of the homologous gap junctions for several reasons. First, the junctions are permeable to molecules as large as biocytin (373 Da), and thus a smaller molecule like Neurobiotin $(286 \mathrm{Da})$ passes readily through the intercellular channels (Vaney et al., 1991b). Second, the AII cells effectively form an unbounded syncytium and changes in the permeability of their gap junctions are thus reflected in the extent of tracer coupling, provided that other conditions are equal. Third, Neurobiotin diffuses through the syncytium for relatively long periods because it does not bind irreversibly to the cytoplasm like Lucifer yellow (Brink and Ramanan, 1985).

Because the AIl amacrine cells in mid-inferior retina have a two- to threefold dendritic field overlap (Vaney, 1990; Mills and Massey, 1991; Vancy ct al., 1991a,b), cach cell can make gap junctions only with its immediate neighbors. If we assume that the AII cells show hexagonal spacing, then the injected Neurobiotin would have to pass through five or six sets of gap junctions in order to label 100 surrounding cells. Thus, with these narrow-field neurons, the extent of Neurobiotin diffusion is likely to be limited by the junctional resistance rather than the cytoplasmic resistance, given that iontophoresed Lucifer yellow completely fills the injected cell within a few seconds. Under high dopamine conditions, each injected AII cell was usually coupled to its immediate neighbors, which in turn were only poorly coupled to more distant neurons. This suggested that the penetration and/or injection of the cell artifactually increased the permeability of its gap junctions, but the true effect of the drug could be assaycd on morc distant gap junctions.

Tracer coupling results from the prolonged diffusion of Neurobiotin through a syncytium, whereas electrotonic coupling results from the instantaneous current carried primarily by hydrated potassium ions. Thus, the extent of tracer coupling is not a measure of the electrotonic space constant of the network. However, the observed changes in tracer coupling will reflect comparable changes in electrotonic coupling, provided that a decrease in gap junction permeability results from a reduction in either the number of connexons or the open probability of the channels, rather than a decrease in their unitary conductance. This condition appears to be met by the gap junctions of fish horizontal cells (Kurz-Isler and Wolburg, 1988; McMahon et al., 1989). With the alternative mechanism, a small constriction in the connexon channels could have a much greater effect on tracer coupling than on electrotonic coupling (Witkovsky and Dcarry, 1992).

\section{Heterologous coupling between AII cells and cone bipolar cells}

The field of tracer-coupled bipolar cells was less extensive than the field of tracer-coupled AII amacrine cells, reflecting the fact that, at each point within the field, the Neurobiotin had to pass through an extra set of gap junctions to label the cone bipolar cells. Although drugs that uncoupled the AII amacrine cells also reduced the field size of labeled bipolar cells, we cannot tell whether these drugs altered the permeability of the gap junctions between amacrine cells and bipolar cells. The problem arises because individual bipolar cells are not further coupled to other neurons, which would provide an extended sink for the diffusing Neurobiotin. For example, take the situation where both the homologous and heterologous gap junctions show reduced permeability. The injected Neurobiotin would be concentrated in the proximal $\Lambda$ II cells, and this would counteract the reduced permeability of the heterologous gap junctions; the intensity of label in the coupled bipolar cells might thus appear normal. The situation where only the heterologous gap junctions show reduced permeability is more straight forward. In this case, the AII amacrine cells would be extensively coupled but the cone bipolar cells would be only poorly labeled. This pattern of tracer coupling was not observed under any of the experimental conditions used in the study. Although it seems probable that the homologous and heterologous gap junctions of AII amacrine cells are modulated by similar mechanisms, this remains to be proven experimentally.

\section{Dopamine reduces coupling between AII cells}

Our experiments showed that exogenous dopamine dramatically reduced the tracer coupling between AII amacrine cells in the rabbit retina and that this effect appeared to be mediated by a $\mathrm{D}_{1}$-like dopamine receptor.

Nanomolar concentrations are effective. Exogenous dopamine reduced the tracer coupling in a concentration-dependent manner. Significant uncoupling was induced by dopamine concentrations as low as $10 \mathrm{nM}$, which reduced the number of coupled AII cells from about 74 to 25 . The uncoupling effect appeared 
to saturate at $1-10 \mu \mathrm{M}$ dopamine, but it is possible that a longer incubation time after injection would have revealed a gradient of coupling with micromolar concentrations of dopamine.

The sensitivity of the tracer coupling between AII amacrine cells in rabbit retina was comparable to that of the electrotonic coupling between horizontal cells in lower vertebrates. Significant uncoupling of intact or dissociated horizontal cells was obtained with 10-15 nM dopamine, whereas maximal uncoupling required 2-10 $\mu \mathrm{M}$ dopamine (Piccolino et al., 1984; DeVries and Schwartz, 1989).

Uncoupling is mediated by a $D_{1}$-like receptor. The uncoupling effect of exogenous dopamine was both mimicked by the specific $\mathrm{D}_{1}$ agonist SKF-38393 and blocked by the specific $\mathrm{D}_{1}$ antagonist $\mathrm{SCH}-23390$. $\mathrm{D}_{1}$ receptors activate adenylate cyclase, and therefore the demonstration that direct stimulation of the production and retention of intracellular CAMP also reduced tracer coupling provided further evidence that the dopaminergic effects were mediated by $D_{1}$ receptors. Moreover, both the dopamine-induced uncoupling and the CAMP-mediated uncoupling showed a similar time course. The receptor appeared to be located on the AII cell itself because exogenous dopamine was still effective when chemical synaptic transmission was blocked by low calcium or cadmium. This was to be expected given that the dopaminergic amacrine cells synapse directly on the cell bodies and proximal dendrites of AII amacrine cells (Pourcho, 1982; Voigt and Wässle, 1987).

$\mathrm{D}_{1}$ receptors are classically regarded as having micromolar sensitivity to dopamine, whereas $D_{2}$ receptors are regarded as having nanomolar sensitivity (Kebabian and Calne, 1979). In the isolated rabbit retina, dose-response curves for the effect of dopamine on cAMP production indicated that $100 \mathrm{~nm}$ dopamine produced no significant increase in cAMP whereas a saturating response required at least $100 \mu \mathrm{M}$ dopamine (Schorderet, 1989; Nowak et al., 1990). Similar results have been obtained for other mammals and for lower vertebrates (Watling et al., 1979; Van Buskirk and Dowling, 1981). How do very low concentrations of dopamine induce significant uncoupling when they do not appear to increase the levels of cAMP significantly? This question appears equally applicable to the horizontal cells in lower vertebrates (DeVries and Schwartz, 1989). We have no ready answer, but note that Makman and colleagues reported that nanomolar concentrations of dopamine stimulated adenylate cyclase activity in rabbit and bovine retinal homogenates, with an $\mathrm{EC}_{50}$ of only 600 and $100 \mathrm{nM}$, respectively (Makman et al., 1980; Makman and Dvorkin, 1986). Thus, the sensitivity to dopamine, as assessed biochemically, appears to be quite variable and may be protocol dependent.

Comparison with horizontal cells. Our experiments indicated that the mechanism underlying dopaminergic uncoupling of the AII amacrine cells in rabbit retina may be substantially similar to that established for horizontal cells in lower vertebrates. That is, dopamine stimulates a $D_{1}$ receptor located in the horizontal cell membrane, which in turn activates adenylate cyclase; the raised level of CAMP then activates a cAMP-dependent protein kinase, probably leading to phosphorylation of the gap junction protein (Teranishi et al., 1983, 1984; Piccolino et al., 1984, 1987; Lasater and Dowling, 1985; Lasater, 1987; DeVries and Schwartz, 1989). However, the coupling between horizontal cells is more sensitive to $\mathrm{pH}$ changes than is the coupling between AII amacrine cells (Negishi et al., 1985; DeVries and Schwartz, 1989), as will be discussed elsewhere (Hampson et al., 1992).

The uncoupling effect of exogenous dopamine on the AII amacrine cells took about $20 \mathrm{~min}$ to develop. This is similar to the time course observed with horizontal cells in the turtle retina, where the uncoupling effects of endogenous dopamine appeared after 6-10 min and were complete within 20-25 min (Piccolino et al., 1987). In both cases, the long time course can be attributed to the fact that the dopamine had to diffuse through the tissue to reach its target cells. By contrast, direct application of exogenous dopamine to dissociated horizontal cells from fish retina induced uncoupling within $1 \mathrm{~min}$ (Lasater and Dowling, 1985; DeVries and Schwartz, 1989).

Effect of endogenous dopamine. When chemical synaptic transmission was blocked with low calcium or cadmium, the AII amacrine cells showed more extensive tracer coupling than under control conditions. This increase might have resulted from blockade of an endogenous transmitter whose normal release reduced the permeability of the gap junctions. Dopamine did not appear to be involved, however, because dopaminergic antagonists on their own did not significantly increase the extent of tracer coupling. An increase was observed in some experiments, but the effect was inconsistent (Fig. 7).

Although exogenous dopamine significantly reduced the tracer coupling under low-calcium conditions, the uncoupling was not as great as that observed under normal conditions. In carp horizontal cells, Van Buskirk et al. (1982) have shown that raising the calcium concentration increased dopamine-stimulated cAMP accumulation but did not influence basal cAMP accumulation. Thus, in our preparation, the exogenous dopamine may have been more effective in the normal medium than in the low-calcium medium.

In the rabbit retina, endogenous dopamine appears to be tonically released, with the turnover and metabolism being $50-$ $100 \%$ greater in light-adapted tissue than dark-adapted tissue (Parkinson and Rando, 1983); similarly, steady illumination of the dark-adapted retina increased the release of endogenous dopamine by about $60 \%$ (Godley and Wurtman, 1988). It was therefore surprising that dopaminergic antagonists had no significant effect on the tracer coupling between AII amacrine cells, given that the coupling was sensitive to nanomolar concentrations of dopamine. Likewise in turtle retina, endogenous dopamine appeared to have little effect on the electrotonic coupling between horizontal cells, in that dopaminergic antagonists did not decrease the spatial summation of the $\mathrm{H} 1$ horizontal cells in moderately dark-adapted retina (Piccolino et al., 1987).

The absence of any effect with flicker stimulation of the isolated retina was less surprising. The light-adapted retina was separated from the retinal pigment epithelium, and thus much of the photopigment was probably bleached; moreover, the pigment epithelium would provide a barrier to dopamine diffusion in vivo. Nowak and Zurawska (1989) reported the curious observation that flicker illumination released ${ }^{3} \mathrm{H}$-dopamine from the whole rabbit retina but not from picces of retina, whereas electrical or potassium stimulation was effective on small pieces.

The release of endogenous dopamine can also be stimulated by veratridine, which activates voltage-dependent sodium channels (Stallcup, 1977; Piccolino et al., 1987). Like exogenous dopamine, veratridine caused dose-dependent uncoupling of the AII amacrine cells that was largely blocked by the $\mathrm{D}_{1}$ antagonist SCH-23390. The residual uncoupling may have been induced by another neurotransmitter released by veratridine, adding further support to the hypothesis that gap junction permeability is modulated by multiple neuronal pathways. A likely candidate is vasoactive intestinal peptide, because it and dopamine stim- 
ulate a common adenylate cyclase in the rabbit retina (Pachter and Lam, 1986).

\section{Functional considerations}

Jensen and Daw $(1984,1986)$ studied the effects of dopaminergic agonists and antagonists on the receptive-field properties of ganglion cells in the rabbit retina. They found that $D_{1}$ antagonists reduced or abolished the surround responses of both On-center and Off-center concentric cells; $\mathrm{D}_{1}$ antagonists also increased the spontaneous activity of the On-center cells and reduced that of the Off-center cells. These effects appeared to be consistent with the hypothesis that the AII amacrine cells are inhibited by the dopaminergic amacrine cells under mesopic conditions (Daw et al., 1989, 1990).

The signal from the On-center AII cells is thought to be relayed to Off-center cells through sign-inverting glycinergic synapses (Pourcho, 1980; Pourcho and Goebel, 1985); physiological evidence for this circuit was provided by the finding, in cat retina, that the light-evoked responses of Off-center ganglion cells were selectively abolished by strychnine under scotopic conditions (Müller et al., 1988). Under mesopic conditions, however, strychnine had little effect on either the center or surround responses in cat and rabbit retinas (Müller et al., 1988; Jensen, 1989), indicating that it is unlikely that the receptivefield surround of retinal ganglion cells originates from the dopaminergic input to AII amacrine cells (Jensen, 1989). Thus, there is no direct evidence that dopamine inhibits the AII amacrine cells under mesopic conditions, as proposed by Daw et al. $(1989,1990)$. The effects of dopaminergic agonists and antagonists have not been studied under scotopic conditions, and therefore dopamine's function in the rod circuit remains a matter of speculation.

The demonstration that the AII amacrine cells show extensive tracer coupling (Vaney, 1991), together with the electron microscopic evidence that these neurons are connected by gap junctions (Famiglietti and Kolb, 1975; Dacheux and Raviola, 1986), securely establishes that the population of AII cells forms a coupled syncytium, like that of each type of horizontal cell. Moreover, it seems probable that the coupling is strongest under scotopic conditions, when the release of endogenous dopamine appears to be minimal (Parkinson and Rando, 1983; Godley and Wurtman, 1988). Electrotonic coupling of the AII amacrine cells would result in greater convergence and divergence in the rod circuit than has previously been calculated (Sterling et al., 1988; Vaney et al., 1991a,b). However, given that each rod bipolar cell provides direct input to several AII amacrine cells (divergence) and that each fourth-order neuron may receive direct input from several AII cells (convergence), the lateral spread of signal through the coupled AII cells may not have a pronounced effect on the receptive-field size of the output ganglion cells.

More critical is the question of whether a quantal rod signal, which is usually transmitted to the inner retina by a pair of rod bipolar cells, would be dissipated within the coupled network of AII amacrine cells. Physiological recordings from cat ganglion cells indicate that each quantal event, whether arising from a photo-isomerization or a thermal isomerization (dark light), gives rise to several spikes in a beta ganglion cell (Barlow et al., 1971); moreover, the same quantal event also stimulates adjacent ganglion cells (Mastronarde, 1983). Thus, any dissipation of a quantal rod signal within the AII network is not sufficient to prevent reliable transmission from the AII amacrine cell(s) to the fourth-order neurons.

For optimal transmission of a quantal rod signal under low scotopic conditions, one might expect an AII amacrine cell to be uncoupled from adjacent AII cells but strongly coupled to On-center cone bipolar cells. This would require, however, that the homologous gap junctions are modulated by a different mechanism from the heterologous gap junctions. Moreover, if the uncoupling of the AII cells is mediated by dopamine, this would further require that dopamine is released maximally in the dark, for which there is no evidence. This study does not directly address either of these issues, notwithstanding the negative finding that the neuronal coupling in the isolated segments of photo-bleached retina was unaffected by dopaminergic antagonists.

We have shown that dopamine, either applied exogenously or released endogenously by depolarization, uncouples the AII amacrine cells from each other and perhaps also from the cone bipolar cells. If we accept that dopamine is released tonically in the light-adapted retina (Parkinson and Rando, 1983; Godley and Wurtman, 1988), then our findings suggest that endogenous dopamine may uncouple the rod circuit from the cone circuit in the inner retina during light adaptation. This would preserve the spatial acuity of the cone circuit by preventing signal flow from the On-center cone bipolar cells through the AII amacrine network. Indeed, under high mesopic conditions, the sustained depolarization of the cone bipolar cells is barely apparent in the AII amacrine cells, whereas under scotopic conditions, the transient depolarization of the AII cells is faithfully reflected in the light-evoked response of the On-center cone bipolar cells (Nelson, 1982; Kolb and Nelson, 1983; Dacheux and Raviola, 1986). Such circuit switching would be compatible with dopamine's other diverse functions, all of which may facilitate the transition from scotopic to photopic vision (Witkovsky and Dearry, 1992).

\section{References}

Baldsridge WH, Ball AK, Miller RG (1987) Dopaminergic regulation of horizontal cell gap junction particle density in goldfish retina. $J$ Comp Neurol 265:428-436.

Barlow HB, Levick WR, Yoon ML (1971) Responses to single quanta of light in retinal ganglion cells of the cat. Vision Res [Suppl] 3:87101

Bennett MVL, Spray DC (1987) Intercellular communication mediated by gap junctions can be controlled in many ways. In: Synaptic function (Edelman GM, Gall WE, Cowan WM, eds), pp 109-135. New York: Wiley.

Blaustein MP (1975) Effects of potassium, veratridine and scorpion venom on calcium accumulation and transmitter release by nerve terminals in vitro. J Physiol (Lond) 247:617-655.

Brink PR, Ramanan SV (1985) A model for the diffusion of fluorescent probes in the septate giant axon of earthworm. Axoplasmic diffusion and junctional membrane permeability. Biophys J 48:299-309.

Dacey DM (1990) The dopaminergic amacrine cell. J Comp Neurol 301:461-489.

Dacheux RF, Raviola E (1986) The rod pathway in the rabbit retina: a depolarizing bipolar and amacrine cell. J Neurosci 6:331-345.

Daw NW, Brunken WJ, Jensen RJ (1989) The function of monoamines in the rabbit retina. In: Neurobiology of the inner retina (Weil er R, Osbourne NN, eds), pp 363-374. Berlin: Springer.

Daw NW, Jensen RJ, Brunken WJ (1990) Rod pathways in mammalian retinae. Trends Neurosci 13:110-115.

Dearry A, Burnside B (1986) Dopaminergic regulation of cone retinomotor movement in isolated teleost retinas: 1 . Induction of cone contraction is mediated by D2 receptors. J Neurochem 46:1006-1021. DeVries SH, Schwartz EA (1989) Modulation of an electrical synapse 
between solitary pairs of catfish horizontal cells by dopamine and second messengers. J Physiol (Lond) 414:351-375.

Dowling JE (1991) Retinal neuromodulation: the role of dopamine. Vis Neurosci 7:87-97.

Ehinger B (1982) Functional role of dopamine in the retina. Prog Retinal Res 2:213-232.

Famiglietti EV (1981) Functional architecture of cone bipolar cells in mammalian retina. Vision Res 21:1559-1563.

Famiglietti EV, Kolb H (1975) A bistratified amacrine cell and synaptic circuitry in the inner plexiform layer of the retina. Brain Res 84:293-300.

Godley BF, Wurtman RJ (1988) Release of endogenous dopamine from the superfused rabbit retina in vitro: effect of light stimulation. Brain Res 452:393-395.

Hampson ECGM, Vaney DI (1992) Modulation of tracer coupling between AII amacrine cells in the rabbit retina: the effect of dopamine. Proc Aust Neurosci Soc 3:64

Hampson ECGM, Weiler R, Vaney DI (1992) Regulation of gapjunction permeability between A-type horizontal cells in rabbit retina: effects of pH and dopamine. Invest Ophthalmol Vis Sci 33:1406

Horikawa K, Armstrong WE (1988) A versatile means of intracellular labeling: injection of biocytin and its detection with avidin conjugates. J Neurosci Methods 25:1-11.

Jensen R (1989) Mechanism and site of action of a dopamine $D_{1}$ antagonist in the rabbit retina. Vis Neurosci 3:573-585.

Jensen RJ, Daw NW (1984) Effects of dopamine antagonists on receptive fields of brisk cells and directionally selective cells in the rabbit retina. J Neurosci 4:2972-2985.

Jensen RJ, Daw NW (1986) Effects of dopamine and its agonists and antagonists on the receptive field properties of ganglion cells in the rabbit retina. Neuroscience 17:837-855.

Kebabian JW, Calne DB (1979) Multiple receptors for dopamine. Nature 277:93-96.

Kita H, Armstrong W (1991) A biotin-containing compound $\mathrm{N}$-(2aminoethyl) biotinamide for intracellular labeling and neuronal tracing studies: comparison with biocytin. J Neurosci Methods 37:141150.

Knapp AG, Dowling JE (1987) Dopamine enhances excitatory amino acid-gated conductances in cultured retinal horizontal cells. Nature 325:437-439.

Kolb $H$ (1979) The inner plexiform layer in the retina of the cat: electron microscopic observations. J Neurocytol 8:295-329.

Kolb H, Famiglietti EV (1974) Rod and cone pathways in the inner plexiform layer of cat retina. Science 186:47-49.

Kolb H, Nelsen R (1983) Rod pathways in the retina of the cat. Vision Res 23:301-312.

Kuan YF, Scholfield CN (1986) Ca-channel blockers and the electrophysiology of synaptic transmission of the guinea-pig olfactory cortex. Eur J Pharmacol 130:273-278.

Kurz-Isler G, Wolburg H (1988) Light-dependent dynamics of gap junctions between horizontal cells in the retina of crucian carp. Cell Tissue Res 251:641-649.

Lasater E (1987) Retinal horizontal cell gap junctional conductance is modulated by dopamine through a cyclic AMP-dependent protein kinase. Proc Natl Acad Sci USA 84:7319-7323.

Lasater EM, Dowling JE (1985) Dopamine decreases conductance of the electrical junctions between cultured retinal horizontal cells. Proc Natl Acad Sci USA 82:3025-3029.

Makman MH, Dvorkin B (1986) Binding sites for [ $\left.{ }^{3} \mathrm{H}\right] \mathrm{SCH} 23390$ in retina: properties and possible relationship to dopamine $D_{1}$-receptors mediating stimulation of adenylate cyclase. Mol Brain Res 1:261270.

Makman MH, Dvorkin B, Horowitz SG, Thal LJ (1980) Properties of dopamine agonist and antagonist binding sites in mammalian retina. Brain Res 194:403-418.

Mariani AP, Kolb H, Nelson R (1984) Dopamine-containing amacrine cells of rhesus monkey retina parallel rods in spatial distribution. Brain Res 322:1-7.

Mastronarde DN (1983) Correlated firing of cat retinal ganglion cells II. Responses of $\mathrm{X}$ - and $\mathrm{Y}$-cells to single quantal events. J Neurophysiol 49:325-349.

McMahon DG, Knapp AG, Dowling JE (1989) Horizontal cell gap junctions: single-channel conductance and modulation by dopamine. Proc Natl Acad Sci USA 86:7639-7643.
Mills SI, Massey SC (1991) Labeling and distribution of AII amacrine cells in the rabbit retina. J Comp Neurol 304:491-501.

Müller F, Wässle H, Voigt T (1988) Pharmacological modulation of the rod pathway in the cat retina. J Neurophysiol 59:1657-1672.

Negishi K, Teranishi T, Kato S (1985) Opposite effects of ammonia and carbon dioxide on dye-coupling between horizontal cells in the carp retina. Brain Res 342:330-339.

Nelson R (1982) AII amacrine cells quicken time course of rod signals in the cat retina. J Neurophysiol 47:928-947.

Nowak JZ, Zurawska E (1989) Dopamine in the rabbit retina and striatum: diurnal rhythm and effect of light stimulation. J Neural Transm 75:201-212.

Nowak JZ, Zawilska J, Sek B, Schorderet M (1990) Light modulates dopamine-regulated Walsh inhibitor activity and dopamine-dependent cyclic AMP accumulation in the rabbit retina. Pol J Pharmacol Pharm 42:457-470.

Pachter JA, Lam DM-K (1986) Interactions between vasoactive intestinal peptide and dopamine in the rabbit retina: stimulation of a common adenylate cyclase. J Neurochem 46:257-264.

Parkinson D, Rando RR (1983) Effect of light on dopamine turnover and metabolism in rabbit retina. Invest Ophthalmol Vis Sci 24:384388.

Piccolino M, Neyton J, Gerschenfeld HM (1984) Decrease of gap junction permeability induced by dopamine and cyclic adenosine $3^{\prime}$ : $5 '$-monophosphate in horizontal cells of turtle retina. J Neurosci 4: 2447-2488.

Piccolino M, Witkovsky P, Trimarchi C (1987) Dopaminergic mechanisms underlying the reduction of electrical coupling between horizontal cells of the turtle retina induced by $d$-amphetamine, bicuculline, and veratridine. J Neurosci 7:2273-2284.

Pourcho R (1980) Uptake of $\left[{ }^{3} \mathrm{H}\right]$ glycine and $\left[{ }^{3} \mathrm{H}\right] \mathrm{GABA}$ by amacrine cells in the cat retina. Brain Res 198:333-346.

Pourcho R (1982) Dopaminergic amacrine cells in the cat retina. Brain Res 252:101-109.

Pourcho RG, Goebel DJ (1985) A combined Golgi and autoradiographic study of $\left({ }^{3} \mathrm{H}\right)$ glycine-accumulating amacrine cells in the cat retina. J Comp Neurol 233:473-480.

Rao G, Barnes CA, McNaughton BL (1986) Intracellular fluorescent staining with carboxyfluorescein: a rapid and reliable method for quantifying dye-coupling in mammalian central nervous system. J Neurosci Methods 16:251-263.

Schorderet M (1989) Receptors coupled to adenylate cyclase in isolated rabbit retina. Neurochem Int 14:387-395.

Seamon KB, Padgett W, Daly JW (1981) Forskolin: unique diterpene activator of adenylate cyclase in membranes and in intact cells. Proc Natl Acad Sci USA 78:3363-3367.

Stallcup WB (1977) Comparative pharmacology of voltage-dependent sodium channels. Brain Res 135:37-53.

Sterling P, Freed MA, Smith RG (1988) Architecture of rod and cone circuits to the On-beta ganglion cell. J Neurosci 8:623-642.

Stewart W (1978) Functional connections between cells as revealed by dye-coupling with a highly fluorescent naphthalimide tracer. Cell 14:741-759.

Strettoi E, Raviola E, Dacheux RF (1989) Synaptic connections of AII amacrine cells in the rabbit retina. Soc Neurosci Abstr 15:967.

Strettoi E, Dacheux RF, Raviola E (1990) Synaptic connections of rod bipolar cells in the inner plexiform layer of the rabbit retina. J Comp Neurol 295:449-466.

Tauchi M, Madigan NK, Masland RH (1990) Shapes and distributions of the catecholamine-accumulating neurons in the rabbit retina. $J$ Comp Neurol 293:178-189.

Teranishi T, Negishi K, Kato S (1983) Dopamine modulates S-potential amplitude and dye-coupling between external horizontal cells in carp retina. Nature 301:243-246.

Teranishi T, Negishi K, Kato S (1984) Regulatory effect of dopamine on spatial properties of horizontal cells in carp retina. J Neurosci 4: $1271-1280$.

Van Buskirk R, Dowling JE (1981) Isolated horizontal cells from carp retina demonstrate dopamine-dependent accumulation of cyclic AMP. Proc Nall Acad Sci USA 78:7825-7829.

Van Buskirk R, Dowling JE (1982) Calcium alters the sensitivity of intact horizontal cells to dopamine antagonists. Proc Natl Acad Sci USA 79:3350-3354.

Vaney DI (1984) 'Coronate' amacrine cells in the rabbit retina have 
the 'starburst' dendritic morphology. Proc R Soc Lond [Biol] 220: 501-508.

Vaney DI (1985) The morphology and topographic distribution of AII amacrine cells in the cat retina. Proc R Soc Lond [Biol] 224:475-488.

Vaney DI (1986) Morphological identification of serotonin-accumulating neurons in the living retina. Science $233:: 444-446$.

Vaney DI (1990) The mosaic of amacrine cells in the mammalian retina. Prog Retinal Res 9:49-100.

Vaney DI (1991) Many diverse types of retinal neurons show tracer coupling when injected with biocytin or Neurobiotin. Neurosci Lett 125:187-190.

Vaney DI (1992) Neurobiotin injection reveals the complete morphology and coupled somatic mosaic of axon-bearing amacrine cells in mammalian retinae. Proc Aust Neurosci Soc 3:63

Vaney DI, Gynther IC, Young HM (1991a) Rod-signal interneurons in the rabbit retina: 2. AII amacrine cells. J Comp Neurol 310:154169.

Vaney DI, Young HM, Gynther IC (1991b) The rod circuit in the rabbit retina. Vis Neurosci 7:141-154.

Voigt T, Wässle H (1987) Dopaminergic innervation of AII amacrine cells in mammalian retina. J Neurosci 7:4115-4128.

Watling KJ, Dowling JE, Iversen LL (1979) Dopamine receptors in the retina may all be linked to adenylate cyclase. Nature 281:578580.

Weiler R, Kohler K, Kolbinger W, Wolburg H, Kurz-Isler G, Wagner H-J (1988) Dopaminergic neuromodulation in the retinas of lower vertebrates. Neurosci Res [Suppl] 8:S183-S196.

Witkovsky P, Dearry A (1992) Functional roles of dopamine in the vertebrate retina. Prog Retinal Res 10:247-292. 